\title{
Sustainability Benefits of RFID Technology in the Apparel Industry
}

\author{
Navodya Denuwara ${ }^{1} \mathbb{D}$, Juha Maijala ${ }^{2} \mathbb{D}$ and Marko Hakovirta ${ }^{1, *}$ \\ 1 Department of Forest Biomaterials, North Carolina State University, Raleigh, NC 27695, USA; \\ hddenuwa@ncsu.edu \\ 2 Stora Enso Oyj, FI-00101 Helsinki, Finland; juha.maijala@storaenso.com \\ * Correspondence: mjhakovi@ncsu.edu; Tel.: +1-919-515-5970
}

Received: 8 October 2019; Accepted: 12 November 2019; Published: 18 November 2019 updates

\begin{abstract}
Digitalization and big data are currently moving many industries forward and creating value-added efficiency improvements, new services, and business models. One area in industrial digitalization is RFID (Radio Frequency Identification) and related sensor technologies with benefits in asset visibility, employee productivity, risk management, loss, and theft mitigation. This literature review article is focused on specifically looking at digitalization in the apparel industry. Due to its complex global network, it has been a challenging industry to implement such technological advancements. Recent novel RFID system integrations have included highly innovative solutions in new store concepts, business models, and product traceability in the value chain. Inventory management has been improved by using RFID technology for creating and updating and for more efficient controls. Also, chain of custody of the various products in apparel and fashion can be more traceable and efficient. Improved customer connectivity and, therefore, customization are also important benefits using these technologies. Most benefits in using RFID in the apparel industry are related to economics and efficiencies. Similarly looking at scientific literature, the majority is focused on the more business-related value creation. In this publication, results of a systematically made literature review focusing on the three dimensions of sustainability (environmental, social, and economic systems) is reported. This review is done using value chain analyses, and it focuses on reported case studies to highlight the sustainability benefits of the RFID technology. According to the literature findings, this is the first review article that reports on the broader sustainability impact of RFID in the apparel industry. The findings show a very limited number of articles and the main focus of the articles found was in environmental aspects (44\%). Following that was economic benefits (36\%), and only a limited amount of research articles was found in social aspects of sustainability (20\%). In addition to identifying the sustainability areas that RFID technology is related to, this article shows other areas of improvements using RFID technology in different parts of the apparel value chain.
\end{abstract}

Keywords: RFID; sustainability; apparel; digitalization; big data; chain of custody; inventory management

\section{Introduction}

The role of corporations and industrial ecosystems in driving sustainability globally is increasing, and corporate involvement in establishing direction, policies, and legislation is becoming a key prerequisite for change [1,2]. Improvements in employment conditions, local purchases, and delivery of safe and affordable products are some clear examples where companies play a critical role in sustainability. Other aspects include investments in infrastructure, reduction of emissions and energy use, reduction of dependence on scarce resources, and workforce training and capacity building. Increasingly, corporate and industrial competitiveness is correlated to the maturity and 
comprehensiveness of their sustainability strategies [3]. We are living in a consumer-driven economy, and therefore, the increasing push and eco-awareness of consumers is connecting competitiveness to sustainability in industries such as the apparel industry. A recent survey shows consumer expectations to be high for eco-friendly products, especially for generation $\mathrm{Z}$ consumers [4]. The role of technology and industrial adaptation of specific goods and services in the context of sustainability is well known [5]. It has created new industrial sectors and shown tremendous opportunities to drive true sustainability-driven growth. However, the justification for technology adaptation is still highly related to the economic benefits driven by its return on investment. Systemic analysis is needed in order to explore the total sustainability benefits of platform technology development and investments. This is especially important when looking at the impact to entire industries and related value chains as in the case of apparel industry's adaptation of RFID (Radio Frequency Identification) technology and its related digitalization, big data, and artificial intelligence [6].

The apparel industry is increasingly adapting digitalization and big data concepts using RFID applications. The main focus on value creation is in areas such as inventory management, asset tracking, product and personnel tracking, item level identification, supply chain management, shipping, payments, counterfeit prevention, and others. RFID technology is a well-known and somewhat mature technology [7]. It uses radio waves to transmit information from RFID tags to an RFID reader, and the technology is mainly used to identify information about objects it is attached to or to track the object's location. From an identification perspective, RFID tags are similar to barcodes; however, RFID tags are not limited to the line-of-sight capability that comes with the optical scanning of a barcode tag and items can be scanned with no limitations to direction near an applicable reader. In addition, this technology also allows scanning of large quantities of RFID-tagged items at once. The apparel industry uses three types of RFID tags: passive tags that have no batteries and draw power from the reader, semi-passive tags that are battery operated and activated in the presence of RFID readers, and active RFID tags that are battery operated and can track the location of assets in real time. The main difference between active and passive tags is the read distance: passive read tags are read around $20 \mathrm{ft}$ while active read tags can be read from a distance of over $100 \mathrm{ft}$. The cost of the tag is a large part of the feasibility issues of using RFID technology. Therefore, dry and wet inlays are used with the distinction of RFID microchips and antenna are either attached to a carrier substrate (dry) or the microchip and antenna are attached to a material, usually PET (polyethylene terephthalate) or PVC (polyvinyl chloride) with an adhesive added (wet). More recently, there are paperboard face tags that have a white paper or a polymer coating on the face. This improves the ability to print logos and numbers. There are also many other RFID chip and antenna construction materials including mylar or polyester films. Many of these materials are an environmental burden especially as the number of tags used in only the retail sector exceeds 8 billion each year [8]. There is a trend of starting to look at more sustainable materials for the tags (conductive inks for antennas and substrates) in order to improve the biodegradability and possibly recycling of the tags. While the impact of the tag materials to sustainability is important, the focus of this review is the total sustainability impact of RFID technology in the business processes and value chain of the apparel industry.

\section{Literature Review}

In this article, a comprehensive literature review was conducted to find and analyze reported benefits of RFID technology in the apparel industry. The focus of this research was on the systemic sustainability impacts of using RFID and related technologies, and therefore, the economic, environmental, and social effects in combination for value chain analysis was the target of this review. There exists a large number of scientific and other publications on the economic and value chain efficiency-related benefits; however, finding data that relates to the impact on sustainability is more challenging. The methodology used was to review and analyze over 100 publications on RFID technology related to the apparel industry. Each finding was then further analyzed to be more presentable and comparable to other reported data. In order to have a good comparison to 
other industries, comparative sustainability factors are also reported in this article. Based on the analyses, several case examples were identified and further investigated using the social, economic, and environmental dimensions of the sustainability framework. Case examples were used instead of broad findings across the apparel industry because of the global scope of the stated industry and because the lack of articles in this topic make it hard to make broad generalizations across the industry.

The fashion industry is the second largest polluter in the world and is accountable for $10 \%$ of the world's carbon emissions [9]; for comparison, the total share of global carbon emissions for the entire US is $14.6 \%$ [10]. Additionally, a $5 \%$ improvement in waste management for the fashion industry would involve 7.5 billion garments and the diversion of 640,000 garments from the landfill, both per year. It takes 2700 liters of water to manufacture $1 \mathrm{t}$-shirt; if all 7.5 billion garments in the industry were $\mathrm{t}$-shirts, it would account for 20,250 billion liters of water used to produce those $t$-shirts [11]. Due to these characteristics of the industry, more research on increasing the sustainability of the apparel industry is needed. RFID has been shown to improve the economic efficiency of operations; however, it has not been translated before to social and environmental benefits. Representative features of the apparel industry include "global scope, high volume, dynamism, fierce competition, and intensive resource use" [12]. These factors generate high environmental risks where natural resources get depleted due to material production and the air and water gets polluted from the harvesting and manufacturing processes of the material. The industry also generates high social risks related to inhumane working conditions where production is outsourced to lower labor cost countries in order for organizations to remain competitive. In general, the implementation of processes to improve the sustainability of a company in the apparel industry is challenging due to the financial pressures on management for lower cost and shorter lead time [13], as well as the above stated features of a global industry. Each industry has different benefits for using RFID specific to their business models. In the consumer food industry, RFID is used to track expired goods. In the healthcare industry, RFID is used to track patient location and patient safety. In the apparel industry, the main benefits in RFID adoption are economic efficiencies such as better supply chain management, theft prevention, reduction in working capital, and better customer services. The increasing global reach of retailers require them to pursue differentiation, better consumer interactions, brand loyalty, and others in order to be competitive in their market. This can be achieved through RFID adoption which can be seen as part of the evolution of the retail industry (such as online purchasing). The operations in Table 1 showcase the impacts of different benefits of integrating RFID technology to the manufacturing and retail operations in the apparel industry.

Table 1. RFID (Radio Frequency Identification) benefits in the apparel supply chain: Listed are the different benefits in different topical areas of economic benefits [14].

\begin{tabular}{|c|c|}
\hline Operations & Impact \\
\hline Visibility and traceability & $\begin{array}{l}\text { RFID technology can help trace the origin of the product and can enable the visibility of the } \\
\text { product's entire supply chain. }\end{array}$ \\
\hline Brand protection & $\begin{array}{l}\text { RFID technology can be tagged to products that enable the product's traceability through their } \\
\text { supply chain. With this, the customer can use smart devices to authenticate the product to see } \\
\text { whether the product is original or a counterfeit. This can efficiently help maintain the brand's } \\
\text { reputation. }\end{array}$ \\
\hline Inventory management & RFID technology is used on retail shop floors to increase stock accuracy and to decrease stockouts. \\
\hline Asset tracking & $\begin{array}{l}\text { RFID can track physical items such as non-sellable parts of offices or of labs or physical items such } \\
\text { as sellable items that require marketing and such. By tracking them, it can dramatically improve } \\
\text { the item's visibility in the supply chain and can enable better return of the item. }\end{array}$ \\
\hline Production processes & $\begin{array}{l}\text { RFID technology can improve goods receiving, product aggregation, pallets/parts movement } \\
\text { tracking, inventory management, and shipping verification in the production part of operations. }\end{array}$ \\
\hline Logistics processes & $\begin{array}{c}\text { RFID technology can improve goods receiving, returnable transport item (RTI) tracking, and } \\
\text { loading verification in the logistic part of operations. }\end{array}$ \\
\hline Retail processes & $\begin{array}{c}\text { RFID technology can improve inventory management, stock counting, and picking validation in } \\
\text { the retail part of operations. }\end{array}$ \\
\hline
\end{tabular}




\section{Methodology}

The methodology used was to examine over 100 publications on RFID technology on the apparel industry using the keywords described in Table 4. However, before starting the research, five research questions were created based on the sustainability potential of certain areas in the apparel value chain (Table 2). Hypothesizing questions helped in creating the keywords (Table 4) used to search for relevant articles for this research. The apparel value chain is displayed in Figure 1, and a detailed analysis of environmental, economic, and social impacts of each value chain area is illustrated in Table 3 . The information was further analyzed to be more presentable and comparable to other reported data.

Table 2. Research questions on sustainability potential in apparel value chain: Questions hypothesized to examine what improvements RFID could have on different sustainability facets of the apparel industry's whole value chain.

\begin{tabular}{|c|c|c|}
\hline Dimension & Objective & Research Question \\
\hline Environmental & Waste reduction & $\begin{array}{l}\text { RQ1. How can RFID impact waste from the apparel } \\
\text { industry? }\end{array}$ \\
\hline Environmental & Increased recycling & RQ2. How can RFID increase the life cycle of clothing? \\
\hline Social & $\begin{array}{l}\text { Transparency/visibility of the } \\
\text { supply chain }\end{array}$ & $\begin{array}{l}\text { RQ3. What is the impact of increased transparency of the } \\
\text { apparel industry through the use of RFID? }\end{array}$ \\
\hline Social & Labor improvement & $\begin{array}{l}\text { RQ4. What effect does RFID have on an apparel } \\
\text { company's use of labor? }\end{array}$ \\
\hline Economic & Return on investment & RQ5. How does RFID pay back its investment costs? \\
\hline
\end{tabular}

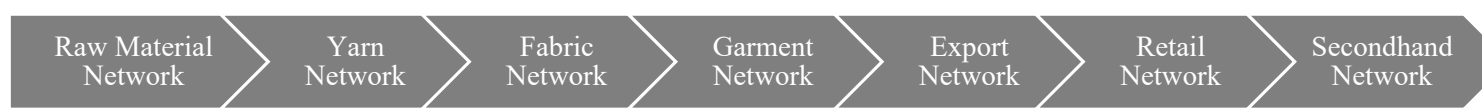

Figure 1. Apparel industry value chain [15].

Table 3. Value chain sustainability impacts: Each operation of the value chain has environmental impacts, societal impacts, and economic impacts. This table was created to summarize the major impacts involved in each step of the apparel value chain.

\begin{tabular}{|c|c|c|c|}
\hline Value Chain & Environmental Impact & Social Impact & Economic Impact \\
\hline Processing natural fibers & $\begin{array}{l}\text { High water use, high fertilizer use, } \\
\text { ecosystem degradation, waste [16] }\end{array}$ & $\begin{array}{l}\text { Child labor, health and safety, } \\
\text { forced labor, role of women in } \\
\text { cultivation, financial dependence } \\
\text { on chemical companies, instability } \\
\text { of cotton prices }[17,18]\end{array}$ & $\begin{array}{l}\text { In 2007, US cotton industry } \\
\text { revenue was } \$ 27 \text { billion [19] }\end{array}$ \\
\hline $\begin{array}{l}\text { Processing synthetic } \\
\text { fibers }\end{array}$ & $\begin{array}{l}\text { High water use, high energy use, } \\
\text { air emissions, nonbiodegradable, } \\
\text { toxic air pollutants [16] }\end{array}$ & Health and safety [17] & $\begin{array}{l}\text { The global synthetic fibers market } \\
\text { size for } 2025 \text { was } \$ 88.5 \text { billion } \\
\text { (revenue) in } 2016 \text { [20] }\end{array}$ \\
\hline Fabric network & $\begin{array}{l}\text { High water use, high energy use, } \\
\text { water pollution, waste, toxic } \\
\text { chemical use, air pollution, } \\
\text { emissions [21] }\end{array}$ & $\begin{array}{c}\text { Forced labor, child labor, low } \\
\text { wages, exposure to high amounts } \\
\text { of pollution [18] }\end{array}$ & $\begin{array}{l}\text { US textile and apparel shipments } \\
\text { totaled } \$ 76.8 \text { billion in } 2018 \text { [22] }\end{array}$ \\
\hline Garment network & $\begin{array}{c}\text { Waste, air pollution, toxic } \\
\text { chemical use, water pollution, air } \\
\text { emissions [21] }\end{array}$ & $\begin{array}{l}\text { Child labor, health and safety, } \\
\text { forced labor, role of women }[17,18]\end{array}$ & $\begin{array}{l}\text { Efficient collection, transportation, } \\
\text { stock management, asset tracking } \\
{[23]}\end{array}$ \\
\hline Export network & $\begin{array}{l}\text { Air pollution and emissions, } \\
\text { waste [21] }\end{array}$ & Wages, working conditions [24] & $\begin{array}{l}\text { Estimated environmental } \\
\text { consulting total revenue in 2023: } \\
\quad \$ 12.4 \text { billion [25] }\end{array}$ \\
\hline Retail network & Waste (plastics, packaging) [21] & $\begin{array}{l}\text { Customer service, wages, working } \\
\text { conditions [26] }\end{array}$ & $\begin{array}{l}\text { Asset tracking, stock management, } \\
\text { payments handling, theft issues, } \\
\text { brand issues }[23,27]\end{array}$ \\
\hline Secondhand use network & $\begin{array}{l}\text { Positive impact: keeps products } \\
\text { from landfill, reuse, benefits of } \\
\text { circular economy [21] }\end{array}$ & $\begin{array}{l}\text { Wages, new business owners } \\
\text { (logistics, laundry, retail) }[25,28]\end{array}$ & $\begin{array}{l}\text { Creates small businesses, } \\
\text { consumer savings [28] }\end{array}$ \\
\hline
\end{tabular}


The apparel industry's value chain shown in Figure 1 is vast in scope. It starts at the raw material production which includes natural fibers such as cotton and wool and includes synthetic fibers such as rayon and polyester. Most apparel value chains depicted in the articles examined appeared similar to the one depicted in Figure 1 with the only exception being the secondhand network. The secondhand network is an increasingly important part of the value chain. Not only does it have a positive environmental impact considering that it increases the life cycle of a piece of apparel but also the industry creates new jobs and businesses.

Analyzing the environmental impact of the different value chains of the apparel industry, it is easy to see that the most common impacts are waste, pollution, and high water/energy usage. This is because apparel production takes up an extensive use of natural resources as well as produces an extensive amount of byproducts as a result of its whole value chain. Analyzing the social impact column, the most common problems found socially in the apparel value chain are child labor and unfair wages. The apparel industry is known for exporting jobs to low-labor-cost countries where the wage is not livable and where child labor occurs but is rarely recognized. The economic impact of the apparel industry varies from each section of the value chain. Overall, the apparel industry has a high economic impact through its creation of jobs, revenue, and other businesses. Socially and environmentally, there is a lot that needs work in the apparel value chain.

Twenty-four cases were identified from over 100 articles using the relationship between RFID impacts and improvements in the value chain and the three sustainability categories. The methodology used was searching the keywords (Table 4) from the following library databases: IEEE/IET (Institute of Electrical and Electronics Engineers/Institution of Engineering and Technology) Electronic Library (IEL), Web of Science, Textile Technology Index, Business Source Complete, Compendex, and the RFID Journal. As stated above, there were no cases of the 100 examined that directly stated sustainability improvements from using RFID technology. Due to this, cases that were RFID improvements in the apparel supply chain were compared to separate sustainability improvement effects from supply chain improvements to indirectly find a relationship between the two. The cases were then organized into environmental, social, and economic categories. Some cases were used in more than one category.

Table 4. Keywords used in methodology: To search for relevant articles on this topic, the above keywords were used.

\begin{tabular}{cc}
\hline Area Under Examination & Keywords \\
\hline Economic & $\begin{array}{c}\text { Economic RFID, profit RFID, economic sustainability RFID, IOT (Internet of Things) } \\
\text { profit, IOT sustainability economic, inventory accuracy, product loss retail, } \\
\text { counterfeiting RFID, cycle time reduction, lean manufacturing time savings, labor } \\
\text { cost and demand for labor, economic efficiencies RFID }\end{array}$ \\
& $\begin{array}{c}\text { Textile fiber recycling, environmental sustainability RFID, RFID energy savings, } \\
\text { virgin fiber sustainability, bobbin/spindle management RFID, inventory accuracy, } \\
\text { recycled fiber, safety stock percentage, apparel energy savings, recycled textiles, } \\
\text { yarn quality RFID, waste RFID, RFID cotton, RFID lean manufacturing, product } \\
\text { loss retail, RFID overproduction, cycle time reduction and waste, RFID tag product } \\
\text { info, waste reduction RFID, RFID washing care, care labeling of clothing, inaccurate } \\
\text { care labeling apparel and waste, RFID and biodiversity, fiber management, apparel } \\
\text { sorting and RFID, smart care labels, inventory waste, RFID waste }\end{array}$ \\
& $\begin{array}{c}\text { Labor productivity, social sustainability RFID, labor cost and profit, secondhand } \\
\text { apparel and rural development, secondhand retail jobs, counterfeiting RFID, } \\
\text { counterfeiting and jobs, supply chain visibility, RFID transparency, social }\end{array}$ \\
& $\begin{array}{c}\text { sustainability supply chain management, transparency child labor, environmental } \\
\text { social governance child labor, social impact of CSR (Corporate Social } \\
\text { Responsibility), reduced labor cost and wages, inventory visibility sustainable } \\
\text { manufacturing, labor cost and demand for labor, RFID job creation, employment } \\
\text { and RFID }\end{array}$ \\
&
\end{tabular}




\section{Results and Discussions}

\subsection{Environmental Benefits of the RFID Technology in Apparel Industry Value Chain}

Environmental impacts of an industry can be numerous. In their LCIA (Life Cycle Impact Assessment) of the cotton industry, Muthukumarana et al. [29] found that around 50\% of the acidification potential for $1000 \mathrm{~kg}$ of cotton fabric is in textile manufacturing. Around $65 \%$ of global warming potential and $60 \%$ of energy demand for $1000 \mathrm{~kg}$ of cotton fabric happens during consumer use when consumers extensively wash, launder, and iron their clothes: 2.1 million tons of $\mathrm{CO}_{2}$ emissions are produced by the apparel industry each year, and over a 100 million trees are cut down each year to make fabric such as rayon, viscose, and modal for apparel, with $30 \%$ of these from ancient and endangered rainforests [30,31].

In the United States, the damage to society due to the use of pesticides was found to be $\$ 9.6$ billion per year [32]. Some of the impacts from the cotton manufacturing industry include large use of irrigated water, soil erosion, an unbalanced use of resources, and others [33].

From a waste management perspective, the fashion industry produces 150 billion garments per year (30\% of which is never sold), and this ends up creating 92 million tons of textile waste [30,34]. A large percentage of waste in the apparel industry is from waste generated in cutting rooms during the apparel manufacturing process, and most of this cutting room waste is dumped in landfills in the US $[35,36]$. The main disposal for cutting room waste are landfills and incineration, which is a large resource loss in regard to the material [37,38].

Even though the environmental impacts of the apparel industry are high, it is possible to improve the situation by using sustainable processes and technologies. For example, organic cotton can reduce the freshwater and marine eutrophication as well as terrestrial ecotoxicity by not using pesticides in organic farming [39]. In the following section, an impact analysis of environmental sustainability was performed and 11 cases where environmental benefits are clearly stated and quantifiable were selected from referenced publications and were concluded as follows.

Cases 1 and 2: Using RFID technology improved dramatically the efficiency, accuracy, and safety of fiber recycling. RFID technology in recycling facilities can help identify where a garment comes from, what material it consists of, and the journey it took through its supply chain [40]. Certain ingredients in garments such as plastics and metals make it harder to recycle their fibers; furthermore, recycling is not always feasible due to the issues in separating dyes and the different polymers used in the garment's original fibers. By introducing RFID to the recycling process, it would be easier to identify which polymers are used in each garment and, by doing this, would effectively simplify the recycling process so unnecessary time and resources are not wasted in trying to recycle what is not recyclable. Furthermore, it has been shown that passive UHF (Ultra High Frequency) RFID tags have the ability to let the readers track the route of the garment through mobile platforms [41,42]. This can make recycling of garments more accessible by helping recycling facilities easily gauge the location of relevant items through an easy to use platform. It can also potentially show consumers where their recycled garments are going to by having the platform trace the path that each of the consumer's garment goes through from garment to fiber to garment. By making recycling of fiber more efficient, it effectively increases the number of garments that get recycled, and this is significant because the high prices of recycling processes are what keeps many potential investors from investing in textile recycling. Fiber recycling is important to the environment because energy savings of recycled fiber versus virgin can be as high as $53 \%$, while the water savings can be even $99 \%$ and the corresponding chemical saving can be $88 \%$. RFID can improve the efficiency of fiber recycling and more recycled fiber can be used in apparel garments, and if this occurs, the above environmental savings can be achieved.

Cases 3-5: Using RFID technology can drastically improve inventory accuracy. One study found that a company had $1 \%$ inaccurate deliveries out of all their deliveries-this accounted to about $30 \%$ of their stock inaccuracy [43]. By tracking which customer buys what product and at what time, RFID helps forecast demand of each stock [44]. This can help create data that could track the accurate amount 
of stock that a store needs to carry. Increased inventory accuracy reduces the need for a retailer to carry safety stock (stock to keep stores from stockouts). Not only does reducing safety stock mean less unnecessary apparel garments in stores that could end up in waste, but it also means less Greenhouse Gas (GHG) emissions from the production and transportation of the stock. Furthermore, Walmart found that increased inventory accuracy has the potential to eliminate extra trips for 100,000 customers daily-this retailer estimated that this would result in a reduction of 80,209 metric tons of $\mathrm{CO}_{2}$ per year [45].

Cases 6-8: Nearly 100 percent of textiles and clothing are recyclable; only 15 percent of consumer-used clothing is recycled [46]. RFID labels can carry care information such as washing/drying instructions and other sorts of information such as how a garment can be recycled and where the nearest secondhand or charity shops can be located. Giving consumers such accurate and detailed information can extend the life of the clothing by several washes and/or weeks to months. Fast fashion garments that are designed for a shorter lifetime produce over $400 \%$ more carbon emission per year than garments that are used for at least a year [9]. In an report titled, "Valuing Our Clothes," [46] the authors state that "If the average life of clothing was extended by just three months, it would reduce their carbon and water footprints, as well as waste generation by 5 to $10 \% . "$

Cases 9 and 10: RFID reduces processing time by approximately $12 \%$. A denim manufacturing plant reduced product loss by $50 \%$ by reducing processing times through RFID [47]. The processing time was decreased by efficiently using RFID technology to track malfunctions and problems that occurred on the production floor-this is what led to the reduced product loss. Only $75 \%$ of pre-consumer waste (i.e., cutting-room waste) gets recycled [48]. By reducing product loss during the manufacturing stages, the amount of pre-consumer waste that could be incinerated gets reduced.

Case 11: Tagged apparel items that require repair and are covered by a warranty can be authenticated by RFID, ensuring that the warranty period of the product has not expired. If consumers have better access to warranty information, they will be more likely to repair their product if it does not meet their standards as opposed to incinerating or recycling it. In many cases, retailers replace damaged products to customers over repairing them-in this case of replacement, many retailers take back the damaged product and offload it to secondhand industries such as discount sellers. Because of this, items that require repair will increase waste in most cases because it requires a replacement product; however, the environmental impact of the previous item can be decreased by sending the damaged item to the secondhand industry. As stated above in environment cases 6-8, "If the average life of clothing was extended by just three months, it would reduce their carbon and water footprints, as well as waste generation by 5 to $10 \% "$ [46].

\subsection{Social Benefits of the RFID Technology in Apparel Industry Value Chain}

Sustainability of a product or service is reliant on the transparency of the product through its whole supply chain. When people have the right information at their fingertips in the appropriate form, they can make decisions that are more sustainability oriented. In the apparel value chain, traceability of the process in fiber production, bale tracking, yarn manufacturing, chemical processing, and labor usage are factors that determine the transparency of it and, in result, affect the social sustainability of the operation. Because social sustainability is the least quantifiable facet of sustainability, while its literature has developed over the years, it remains still a field least explored [49].

The environmental dimension is more prominently researched in the sustainable supply chain management field than the social dimension because it is a quantifiable discipline with data that is easy to track and trace. In business, social sustainability performance issues include good manufacturing conditions, child labor, discrimination, wages, overtime reduction, fire prevention, working conditions, health and safety, and others. Poor working conditions are mostly caused by factory managers trying to stay competitive while retailers keep asking for cheaper prices [14]. One of the main reasons that it is hard to identify if forced or child labor is taking place in the supply chain is because retailers are most often focused on the tier 1 suppliers and manufacturers; however, most of the work gets done 
by tier 2 and tier 3 suppliers. This means that the people putting on the buttons or putting the soles to your shoes are often trafficked and invisible [50]. Impact analysis of the social sustainability was performed and 5 clearly stated concrete cases were selected as examples from referenced publications.

Case 1: One company examined in an RFID in apparel article measured a 4\% economic saving in their store staffing costs after RFID rollout, and in overall savings, this would amount to US \$462 million if rolled out to the 10 companies in the study: Adidas, C\&A, Decathlon, Lululemon, Jack Wills, John Lewis, MARC O'POLO, Marks \& Spencer, River Island, and Tesco [39]. Reduced labor costs could mean reduction in overtime hours for employees, increased profitability, increased employment, or increased wages.

Case 2: The US economy loses between $\$ 200$ and $\$ 250$ billion per year and around 750,000 American jobs because of product counterfeiting [51]. RFID tags makes it possible to verify the authenticity of a product and, hence, to detect and prevent counterfeiting. By preventing counterfeiting, RFID can potentially save thousands of American jobs.

Case 3: A report found that 15\% of apparel brands did not know of their first-tier suppliers and that less than $10 \%$ of brands had $100 \%$ information about raw material suppliers [6]. RFID can enable the sharing of real-time information and the tracking and tracing of goods which can result in total visibility of the supply chain. Visibility of a product enables firms and consumers to make more environmentally and socially informed decisions on purchasing. Traceability of a product helps in bringing supply chain actors together for a consumer or a firm to see in one place. This visibility enables firms and consumers to make more environmentally and socially informed decisions on purchasing that can be verified by external decision makers who know of the different stakeholders inside the traceability network [52].

Case 4: As stated in cases 6-8 of the environment section, RFID labels can carry care information such as how a garment can be recycled and where the nearest secondhand or charity shops can be located. The United States textile recycling industry creates more than 17,000 jobs. By giving recycling apparel information to consumers, the amount of recycling of those apparels are likely to increase. This in turn creates small businesses and more local jobs because a majority of these recycling facilities employs around 35 to 50 workers each [46]. One third of all garments produced ended up in a landfill-if this material was sent to a secondhand facility, over $\$ 175$ million in income would be generated [53]. By easing reuse processes for customers, the secondhand industry can grow significantly.

Case 5: In the current economic reality, it is becoming easier for companies to adopt RFID technology due to the globalization of value chains. For instance, the Belt and Road Imitative (BRI) is a global trade policy of China that aims to connect different countries by developing and linking their supply chains [54]. Many developing countries are still only doing cutting and sewing businesses, but only organizations with a good supply chain can play an important role with international buyers [54]. RFID is a solution to link supply chains because it can trace the location history of a product, which enables small apparel-producing companies to track where a product is coming from and, as a result, enhance their supply chain. By linking supply chains, RFID can help the infrastructure development of many countries through the use of better global value chains.

\subsection{Economic Benefits of the RFID Technology in Apparel Industry Value Chain}

The apparel supply chain is global and complex in nature. It is a $\$ 3$ trillion global industry with US $\$ 348,300$ million in revenue with a revenue growth around $1.9 \%$ for 2020 [55]. Due to its complexity and reach, the apparel industry has a lot of economical sustainability issues. The more apparent issues include a livable wage, jobs and stability, fair procurement prices of products, local economic development, and networking for employees. These factors are ones that apply to most societies and to most individuals that are associated with an apparel corporation. Additional sustainability factors that are economic in nature are environmental performance status, detection of potential improvements in the supply chain, environmental benchmarking, and better marketing abilities such 
as using environmental product declarations or eco-labeling. Impact analysis of the economic aspects of sustainability was performed, and 9 quantifiable and concrete cases were selected from referenced publications and were concluded.

Case 1: 10 companies (e.g. Adidas, C\&A, Decathlon, Lululemon, Jack Wills, and John Lewis) measured impact of their RFID program. The overall improvements in sales was typically between $1.5 \%$ and $5.5 \%$. One company even claimed that "For every 3\% improvement in stock accuracy, they had experienced a 1\% uplift in sales." In the same study, stock availability increased to $90 \%$, stock reduction was shown between $2-13 \%$, and shrinkage losses were reduced by $15 \%$ [43].

Cases 2 and 3: Inventory accuracy improvements in the region of $65 \%$ to $99 \%$ was reported in the study above that tested 10 companies in the fashion industry [43]. Another company boosted its inventory accuracy by $30 \%$ across its 220 stores thanks to an RFID-based solution installed at their retail stores [50]. By increasing inventory accuracy, the customer is more likely to find the exact product they want, and this in turn increases sales.

Cases 4-6: "RFID reduced human errors from labor-intensive and error-prone operations such as counting, manual data entry, and put-away" [53]. One study saw human location errors decrease by $90 \%$ after implementing RFID in their warehouses: $50-80 \%$ of these warehouse costs are in labor associated with material handling [56]. Using automated routing, receiving, shipping, and inventory control applications through RFID technology can save money for the company by reducing labor costs and, in turn, increasing investment back in the company [43].

Case 7: Through the use of RFID, read rates of apparel tags can be improved up to $100 \%$. High read-rates can help with antitheft measures, and time savings were shown to have increased to $87 \%$ in another retailer. Both improvements help increase sales [57].

Case 8: Sapati, a Brazilian shoe store, reported a $100 \%$ increase in its sales after testing RFID technology in their stores [58]. This could have been possible due to the decreased backlogs from the use of RFID in their "garment manufacturing" process.

Case 9: Improved product sorting in the return-back stage due to RFID helps reduce processing time of fibers that could potentially lose up to $10-20 \%$ of their value simply due to time delays in processing [59]. This improvement increases the work efficiency and service quality of the distribution center, saves on manpower cost, decreases the occurrence of human error, and improves logistics service to customers.

\section{Conclusions}

RFID in the fashion industry helps to improve inventory management, to integrate the fashion business model, to improve efficiency of operations, and to increase the responsiveness of the fashion cycle [60]. Global adoption of RFID will be increasingly witnessed in the upcoming years, especially in the apparel industry. In any event, sustainable production of garments and fabric remain essential and this can be nurtured if it is supported by sound business practices [61]. One of the reasons sustainability of the apparel industry is examined in this paper is due to the actions of consumers regarding "green" apparel products. Research has found that millennials and Generation Z are increasingly environmentally conscious regarding the apparel they buy and so businesses producing and selling "green" garments have been shown to have more loyal customers due to their sustainable practices [62]. Since purchasing power is increasingly shifting to the newer generations, reasons for RFID adoption due to sustainability reasons will directly increase as well. Furthermore, RFID adoption also indirectly increases the environmental consciousness of corporations who in previous generations have only focused on the economic incentives of purchasing and selling products. This bodes well for the future where environmental concerns will be more and more important. Currently however, because sustainability comes with real costs that are either pushed upstream on suppliers or downstream to consumers, many businesses are reluctant to jump on the "green" bandwagon due to high costs. This paper examines how RFID adoption in the retail industry can be economically beneficial to a company while helping the environment and society as well. 
One finding of this research is that there is an indirect negative relationship between RFID technology and waste. RFID directly increases inventory accuracy, which as a result impacts the safety stock (stock to keep stores from stockouts) that a retailer carries. By reducing safety stock, unnecessary waste is kept out of retail shops and landfill. Therefore, when RFID technology is increasingly used in the value chain, the production of waste can be decreased. The second main finding related to waste reduction is that RFID can increase the life cycle of clothing by reducing pre-consumer waste. Pre-consumer waste goes directly to incineration or recycling after the garment is produced. However, garments that go directly to the consumer have a use stage before going to incineration or recycling. By reducing pre-consumer waste and by increasing consumer waste, RFID indirectly increases the life cycle of clothing. This is significant because, as a report stated above [46], increasing the life cycle clothing by several months has a positive impact on the environmental due to the energy saved from product incineration.

The least amount of case examples found were in the social impact category. It was anticipated that transparency through the use of RFID in the value chain would directly translate into better Corporate Social Responsibility (CSR) efforts and in turn environmentally informed consumers. However, no results were found in the research to answer this hypothesis. Future work could be done to examine what actions corporations/companies take with the visibility information that RFID provides by increasing the transparency of the supply chain. One main finding in this category was on labor usage. RFID decreases labor costs by making manufacturing and production processes more automated and more efficient. Reduced labor costs could mean a reduction in overtime hours for employees, increased profitability, increased employment, or increased wages for employees.

Economically, there are several ways RFID can pay back its investment: First, with supply chain efficiencies such as speed gains and error reductions in warehouse processing, inventory and returns control, automatic filing of missing items, and etc. Second, it reduces labor costs by using automated routing, receiving, shipping, and inventory control applications. Third is increased profit by better customer services such as faster checkouts and electronic payments.

The case examples examined do not showcase a direct relationship between RFID adoption and sustainability for the apparel industry; rather, they show connections between RFID benefits in the apparel industry and sustainability issues in the apparel industry. These connections result in an indirect relationship between RFID and sustainability; however, future work can be done to establish a more empirically direct relationship between the above stated factors. Specifically, more work can be done to examine the following:

- Employment-Does RFID technology increase/decrease overall employment levels in a company/surrounding society? What empirical relationship exists between reduced labor costs and employment level?

- Greenhouse gas emissions from improved machine maintenance-RFID improves machine maintenance by making it easier to track and trace malfunction issues. Machines produce a lot of GHG emissions during its use stage, and it would be useful to examine the relationship between improved machine maintenance and GHG emissions because extending the life of a machine through improved maintenance might reduce overall GHG emissions.

- Secondhand apparel industry—Does RFID technology use by primary retailers impact the secondhand apparel industry? RFID has been shown to improve inventory accuracy; this means that more products are going into the hands of customers over laying in facilities waiting to get incinerated. By increasing the amount of product that goes into customer's hands, the amount of product that will trickle into the secondhand apparel industry after consumer use increases. There is ongoing work to find an RFID tag solution that would live long enough for use in secondhand industries; however, the current solutions are too expensive. Any work to explore this area would have to be done later in the future since no current tag that could work in this capacity is used in the fashion industry. To make a current prediction, an empirical relationship between 
apparel going into secondhand stores and increased inventory accuracy can illustrate a significant relationship between RFID and secondhand industries.

- Pre-consumer waste and consumer waste-What impact does RFID have on waste that is divided into pre-consumer and consumer waste? Only $15 \%$ of clothing that is used by a consumer ends up getting recycled while $75 \%$ of clothing that is pre-consumer (does not reach the consumer) waste ends up getting recycled. RFID can potentially increase consumer waste and can reduce pre-consumer waste. An empirical relationship between waste and RFID implementation should be examined to find more concrete evidence on whether RFID improves or decreases overall apparel waste that would be incinerated.

- Life cycle impact assessment of clothing-By increasing the life cycle of a garment, its environmental impact gets significantly reduced. A relationship between the life cycle of a garment and RFID technology should be examined to easily find one part of the environmental impact of RFID.

As stated above, the main limitation of this study is the lack of empirical articles examining the direct relationship of the variables in focus on this research. The relationship between RFID technology and the sustainability of the apparel industry is important due to the increasing use of RFID tags in apparel stores. These tags can be used throughout the value chain of the industry to provide social and environmental benefits to society that are greater than the purely economic benefits that corporations reap. This study examines the apparel industry; however, it is not the only industry that uses RFID technology. In addition to the future work areas listed above, more work can be done to widen the scope of interest such as studying the sustainability of RFID technology in industries such as the perishable goods industry, the healthcare industry, the airline industry, and much more.

One thing to note in this literature review of the sustainability benefits of the RFID tags is that there are a number of issues accompanying the adoption of RFID tags in the apparel industry. The main concern is the issue of privacy [63]. Some of the main benefits discussed above that RFID can have in the environmental impact category of the apparel industry is that RFID can promote the secondhand industry by using RFID tags in the clothing to find the nearest secondhand shop and to increase the efficiency of apparel recycling by identifying the types of fiber in each garment. These cases would require the garment to come out of clothing stores with the RFID tag still attached. When this happens, these RFID tags have the potential to be hacked because currently, RFID tags are not able to completely secure perfect privacy. However, it is very unlikely to happen due to the read distance and read capabilities of RFID readers which can only read certain types of information which do not include privacy information of consumers [64]. Based on the findings of this article, privacy concerns do not need to be the singular reason for limiting the use of RFID tags for sustainability benefits when the benefits are compared with the issues of tag adoption.

Author Contributions: Conceptualization, M.H. and J.M.; methodology, M.H. and N.D.; formal analysis, N.D., M.H. and J.M.; investigation, N.D., M.H. and J.M.; resources, M.H. and J.M.; data curation, N.D. and M.H.; writing —original draft preparation, N.D. and M.H.; writing-review and editing, N.D., M.H. and J.M.; visualization, N.D. and M.H.; supervision, M.H.; project administration, M.H.; funding acquisition, M.H.

Funding: This research was funded by Stora Enso Oyj and North Carolina State University.

Conflicts of Interest: The authors declare no conflict of interest.

\section{References}

1. Oerlikon. The Fiber Year 2008/2009: A World Survey on Textile and Nonwovens Industry. Available online: https://www.oerlikon.com/ecomaXL/get_blob.php?name=Layout_Fibre_Year_08_09_290509_s_ screen.pdf (accessed on 29 October 2019).

2. WBCSD. What We Do. Available online: www.wbcsd.org/Overview/Our-approach (accessed on 29 October 2019). 
3. TurnKey Group. Drivers of Sustainability—Role of Stakeholders and Business Drivers. Available online: www.turnkeygroup.net/key-drivers-sustainability-role-stakeholders-business-drivers/ (accessed on 29 October 2019).

4. CGS. CGS Survey Reveals 'Sustainability' Is Driving Demand and Customer Loyalty. Available online: https://www.cgsinc.com/en/infographics/CGS-Survey-Reveals-Sustainability-Is-Driving-Demandand-Customer-Loyalty (accessed on 29 October 2019).

5. Nimbalker, G.; Cremen, C.; Wrinkle, H. The truth behind the barcode: The Australian Fashion Report. J. Home Econ. Inst. Aust. 2013, 20, 25-35.

6. Liu, J.H.; Gao, W.D.; Wang, H.B.; Jiang, H.X.; Li, Z.X. Development of Bobbin Tracing System Based on RFID Technology. J. Text. Inst. 2010, 101, 925-930. [CrossRef]

7. Advanced Mobile Group. 10 Companies, 10 Cost Effective RFID Solutions. Available online: www. advancedmobilegroup.com/blog/10-companies-10-rfid-solutions (accessed on 29 October 2019).

8. CYBRA. 5 Huge RFID Statistics for 2017. Available online: https://cybra.com/5-huge-rfid-statistics-2017/ (accessed on 29 October 2019).

9. Conca, J. Making Climate Change Fashionable-The Garment Industry Takes on Global Warming. Available online: https://www.forbes.com/sites/jamesconca/2015/12/03/making-climate-change-fashionablethe-garment-industry-takes-on-global-warming/\#44c047d479e4 (accessed on 29 October 2019).

10. Ghosh, I. All the World's Carbon Emissions in One Chart. Available online: https://www.visualcapitalist. com/all-the-worlds-carbon-emissions-in-one-chart/ (accessed on 29 October 2019).

11. Rudenko, O. Apparel and Fashion Overproduction Report with Infographic. Available online: https: //sharecloth.com/blog/reports/apparel-overproduction (accessed on 29 October 2019).

12. Garcia-Torres, S.; Albareda, L.; Rey-Garcia, M.; Seuring, S. Traceability for Sustainability-Literature Review and Conceptual Framework. Supply Chain Manag. Int. J. 2019, 24, 85-106. [CrossRef]

13. Köksal, D.; Jochen, S.; Martin, M. Social Sustainability in Apparel Supply Chains-The Role of the Sourcing Intermediary in a Developing Country. Sustainability 2018, 10, 1039. [CrossRef]

14. Zetes. RFID in Supply Chain. Available online: www.zetes.com/en/technologies-consumables/rfid-insupply-chain (accessed on 29 October 2019).

15. Martin, M. Global Supply Chains: Deciding the Way Forward-Supply Chain 24/7. Available online: http://www.supplychain247.com/article/global_supply_chains_deciding_the_way_forward (accessed on 29 October 2019).

16. NRDC. Fiber Selection: Understanding the Impact of Different Bers Is the Rst Step in Designing Environmentally Responsible Apparel. Available online: https:/www.nrdc.org/sites/default/files/CBDFiber-Selection-FS.pdf (accessed on 29 October 2019).

17. Muthu, S.S. Roadmap to Sustainable Textiles and Clothing: Environmental and Social Aspects of Textiles and Clothing Supply Chain; Springer Singapore: Singapore, 2014.

18. Cotton Commodity Atlas Research Page with a Map. Available online: https://www.verite.org/project/cotton3/ (accessed on 29 October 2019).

19. Overview of the US Cotton Industry. Available online: https://www.cotton.org/pubs/cottoncounts/upload/ Cotton-Industry-Overview_Jan-19-2011.pdf (accessed on 29 October 2019).

20. Synthetic Fibers Market Size Worth $\$ 88.5$ Billion by 2025: CAGR: 6.3\%. Available online: https://www. grandviewresearch.com/press-release/global-synthetic-fibers-market (accessed on 29 October 2019).

21. Environmental Impact of the Textile and Clothing Industry. Available online: http://www.europarl.europa. eu/RegData/etudes/BRIE/2019/633143/EPRS_BRI(2019)633143_EN.pdf (accessed on 29 October 2019).

22. Davis, R. 2019 State of the U.S. Textile Industry. Available online: https://www.textileworld.com/textileworld/features/2019/05/2019-state-of-the-u-s-textile-industry/ (accessed on 29 October 2019).

23. Logistics Management Systems: How Warehouse, Transportation, and Distribution Software Work. Available online: https://www.altexsoft.com/blog/business/logistics-management-systems-how-warehousetransportation-and-distribution-software-work/ (accessed on 29 October 2019).

24. Milberg, W.; Matthew, A. Economic Development and Working Conditions in Export Processing Zones: A Survey of Trends. Available online: http://citeseerx.ist.psu.edu/viewdoc/download?doi=10.1.1.490.1514\& rep=rep1\&type $=$ pdf (accessed on 29 October 2019). 
25. Huhn, P. Forecast: Industry Revenue of 'Environmental Consulting Services' in the U.S. 2011-2023. Available online: https://www.statista.com/forecasts/409750/environmental-consulting-services-revenue-in-the-us (accessed on 29 October 2019).

26. Working Conditions in the Retail Sector. Available online: https://www.eurofound.europa.eu/publications/ report/2012/working-conditions-in-the-retail-sector (accessed on 29 October 2019).

27. Speights, D.; David, S. RESEARCH: Retail Theft and Loss Prevention Analytics. Available online: https: //losspreventionmedia.com/retail-theft-loss-prevention-analytics/ (accessed on 29 October 2019).

28. 2019 Fashion Resale Market and Trend Report. Available online: https://www.thredup.com/resale (accessed on 29 October 2019).

29. Muthukumarana, T.T.; Karunathilake, H.P.; Punchihewa, H.K.G.; Manthilake, M.M.I.D.; Hewage, K.N. Life Cycle Environmental Impacts of the Apparel Industry in Sri Lanka: Analysis of the Energy Sources. J. Clean. Prod. 2018, 172, 1346-1357. [CrossRef]

30. Farra, E. 5 Takeaways from Last Night's Future of Fashion Sustainability Panel. Available online: www. vogue.com/article/fast-fashion-environmental-impact-sustainability-parsons-zady (accessed on 29 October 2019).

31. MacCarthy, L. Canopy, Rainforest Alliance Launch First-Ever Audit for Rayon-Viscose Supply Chain. Available online: https://sustainablebrands.com/read/supply-chain/canopy-rainforest-alliance-launch-firstever-audit-for-rayon-viscose-supply-chain (accessed on 29 October 2019).

32. Pimentel, D. Environmental and economic costs of the application of pesticides primarily in the United States. Environ. Dev. Sustain. 2005, 7, 229-252. [CrossRef]

33. WWF Report. Cotton Market Sustainability in India; WWF-India: New Delhi, India, 2012.

34. Chung, S.-W. Fast Fashion Is 'Drowning' the World. We Need a Fashion Revolution! Available online: www.greenpeace.org/international/story/7539/fast-fashion-is-drowning-the-world-we-need-afashion-revolution/ (accessed on 29 October 2019).

35. Divita, L.; Dillard, B.G. Recycling textile waste: An issue of interest to sewn products manufacturers. J. Text. Inst. 1999, 90, 14-26. [CrossRef]

36. Negulescu, I.; Kwon, H.; Collier, B.J.; Pendse, A. Recycling cotton from cotton/polyester fabrics. Text. Chem. Colorist 1998, 30, 31-35.

37. Woolridge, A.C.; Garth, D.; Ward, P.S.; Philips, M.C.; Simon, G. Life cycle assessment for reuse/recycling of donated waste textiles compared to use of virgin material: An UK energy saving perspec-tive. Resour. Conserv. Recycl. 2006, 46, 94-103. [CrossRef]

38. Larney, M.; van Aardt, A.M. Case Study: Apparel Industry Waste Management: A Focus on Recycling in South Africa. Waste Manag. Res. 2010, 28, 36-43. [CrossRef]

39. Beton, A.; Dias, D.; Farrant, L.; Gibon, T.; Le Guern, Y.; Desaxce, M.; Perwueltz, A.; Boufateh, I. Environmental improvement potential of textiles (IMPRO-textiles). In JRC Scientific and Technical Reports; Wolf, O., Cordella, M., Eds.; European Commission: Brussels, Belgium, 2014.

40. Leal Filho, W.; Ellams, D.; Han, S.; Tyler, D.; Boiten, V.; Paco, A.; Moora, H.; Balogun, A.L. A Review of the Socio-Economic Advantages of Textile Recycling. J. Clean. Prod. 2019, 218, 10-20. [CrossRef]

41. Liu, R.; Goran, H.; Andreas, Z. On Tracking Dynamic Objects with Long Range Passive UHF RFID using a Mobile Robot. Int. J. Distrib. Sens. Netw. 2015, 11, 781380. [CrossRef]

42. Liu, R.; Koch, A.; Zell, A. Mapping UHF RFID tags with a mobile robot using a 3D sensor model. In Proceedings of the 2013 IEEE/RSJ International Conference on Intelligent Robots and Systems, Tokyo, Japan, 3-7 November 2013; pp. 1589-1594.

43. Beck, A. Measuring the Impact of RFID in Retailing: Keys Lessons from 10 Case-study Companies. Tech. Rep. 2018. [CrossRef]

44. Marr, B. How Fashion Retailer H\&M Is Betting on Artificial Intelligence and Big Data to Regain Profitability. Available online: www.forbes.com/sites/bernardmarr/2018/08/10/how-fashion-retailer-hm-is-betting-onartificial-intelligence-and-big-data-to-regain-profitability/\#4b5220095b00 (accessed on 29 October 2019).

45. Downey, L. RFID and Global Warming. Available online: www.rfidjournal.com/articles/view?9300/3 (accessed on 29 October 2019).

46. Valuing Our Clothes: The True Cost of How We Design, Use, and Dispose of Clothing in the UK. Available online: http://www.wrap.org.uk/sites/files/wrap/VoCFINALonline20120711.pdf (accessed on 29 October 2019). 
47. Nayak, R. Radio Frequency Identification (RFID) Technology and Application in Fashion and Textile Supply Chain; CRC Press: Boca Raton, FL, USA, 2019.

48. Berthon, M.A. Textile Waste Comes in Many Forms: Cooper Hewitt, Smithsonian Design Museum. Available online: www.cooperhewitt.org/2016/11/15/textile-waste/ (accessed on 29 October 2019).

49. Shuai, W.; Chongqi, M.; Hanming, L. Yarn Quality Tracking System Based-on RFID. In Proceedings of the 2010 International Conference on Computer and Information Application, Tianjin, China, 3-5 December 2010. [CrossRef]

50. Nakamba, C.C.; Chan, P.W.; Sharmina, M. How does social sustainability feature in studies of supply chain management? A review and research agenda. Supply Chain Manag. Int. J. 2017, 22, 522-541. [CrossRef]

51. Suhrawardi, R. The Big Issues Facing Fashion in 2019. Available online: www.forbes.com/ sites/rebeccasuhrawardi/2019/01/16/the-big-issues-facing-fashion-in-2019/\#202238a523a9 (accessed on 29 October 2019).

52. Swedberg, C. U.K. Home Goods and Apparel Retailer Boosts Accuracy with RFID. Available online: www.rfidjournal.com/articles/view?18556 (accessed on 29 October 2019).

53. Kumar, V.; Agrawal, T.K.; Wang, L.; Chen, Y. Contribution of Traceability towards Attaining Sustainability in the Textile Sector. Text. Cloth. Sustain. 2017. [CrossRef]

54. Le, Q.L.; Tran, V.A.; Duc, N.B.L. The Belt and Road Initiative and Its Perceived Impacts on the Textile and Garment Industry of Vietnam. J. Open Innov. 2019, 5, 59. [CrossRef]

55. Apparel-United States: Statista Market Forecast. Available online: www.statista.com/outlook/90000000/ 109/apparel/united-states\#market-revenue (accessed on 29 October 2019).

56. Tajima, M. Strategic Value of RFID in Supply Chain Management. J. Purch. Supply Manag. 2007, 13, $261-273$. [CrossRef]

57. Thiesse, F.; Jasser, A.-K.; Elgar, F. Understanding the Value of Integrated RFID Systems: A Case Study from Apparel Retail. Eur. J. Inf. Syst. 2009, 18, 592-614. [CrossRef]

58. Perin, E. Shoe Shop Doubles Sales via RFID. Available online: www.rfidjournal.com/articles/view?16936 (accessed on 29 October 2019).

59. Blackburn, J.D.; Guide, V.D.R., Jr.; Souza, G.C.; Van Wassenhove, L.N. Reverse Supply Chains for Commercial Returns. Calif. Manag. Rev. 2004, 46, 6-22. [CrossRef]

60. Kabukcu, E. RFID adoption for agility in the fashion business. J. Manag. Mark. Logist. 2017, 4, $209-216$. [CrossRef]

61. Barrie, L. Outlook 2019-Apparel Industry Challenges and Opportunities. Available online: www.just-style. com/analysis/outlook-2019-apparel-industry-challenges-and-opportunities_id132645.aspx (accessed on 29 October 2019).

62. Dabija, D.-C. Enhancing Green Loyalty towards Apparel Retail Stores: A Cross-Generational Analysis on an Emerging Market. J. Open Innov. Technol. Mark. Complex. 2018, 4, 8. [CrossRef]

63. Jung, K.; Lee, S. A Systematic Review of RFID Applications and Diffusion: Key Areas and Public Policy Issues. J. Open Innov. Technol. Mark. Complex. 2015, 1, 9. [CrossRef]

64. Murray, C. Privacy concerns mount over retail use of RFID technology. EE Times 2003, 2, 4-5.

(C) 2019 by the authors. Licensee MDPI, Basel, Switzerland. This article is an open access article distributed under the terms and conditions of the Creative Commons Attribution (CC BY) license (http://creativecommons.org/licenses/by/4.0/). 